\title{
Instructor Attribute and Feedback to Empower Mature Learners in ODL Education
}

\author{
https://doi.org/10.3991/ijet.v17i03.27277 \\ Zaleha Abdullah( $\left.{ }^{\bowtie}\right)$, Mohd Nihra Haruzuan Mohamad Said \\ Universiti Teknologi Malaysia, Kuala Lumpur, Malaysia \\ zac@utm.my
}

\begin{abstract}
With the outbreak of Covid-19, Open and Distance Learning (ODL) has become even popular particularly among those who aim to pursue postgraduate studies. ODL provides alternative for many to study while working or while raising a family. Nevertheless, the lack of student engagement and noncompletion rate in ODL programs were reported higher than in traditional programs. One of the main factors is due to the instructor-student interaction issue. The objective of this qualitative study was to understand the issue by looking at instructor attributes and types of feedback required by the students. The data were collected via semi-structured interviews with a small sample of university postgraduate students and academics in Malaysia and were analysed using thematic analysis and data triangulation. The results show two factors that need attention to improve instructor-student interaction and make ODL a better learning option for mature learners: instructor empathy and feedback to empower learners. These findings cannot be generalised without further research but are able to provide some information on the important factors to consider in preparing instructors for learning delivery completely online.
\end{abstract}

Keywords-instructor attribute, feedback, mature learners, ODL

\section{Introduction}

Open and Distance Learning education (ODL) has gained more acceptance during the Movement Control Order (MCO) period to break the chain of COVID-19 infections. It is recognized as one of the safest ways to continue education during the pandemic. Professional and part-time learners particularly able to improve their skills without having to pursue formal learning in universities. Thus, they are able to make life or their work more meaningful. Universiti Teknologi Malaysia (UTM) became the first public university in Malaysia to offer ODL. Nevertheless, there is much to learn in improving the existing ODL courses. Learning through fully online depends heavily on internet access but having good internet connectivity and high-quality equipment does not determine successful learning [1]. Numbers of research argues that online instructors need to also possess strong professional teaching dispositions to truly be effective educators [2]. Studies indicate that not necessarily instructors who teach successfully 
face- to- face can be equally effective online [3]. Online instructors need to have certain skills such as the ability to interact actively and provide quality feedback [4]. Matters involving the selection of qualified instructors in teaching ODL courses should not be taken lightly. Studies suggested for effective methods to be applied in recruiting and retaining online instructors - among requirements to become an online instructor are willingness to explore innovative teaching, able to create opportunities and new programs, and have extensive knowledge in the field of educational technology [5]. But more concerning, several ODL studies conducted in Malaysian public universities found that there was a research gap on the instructor-student interaction $[6,7]$ and this deserves attention.

Studies have highlighted the association of interactions with the use of new technologies and social media in ODL [8-11], yet only few studies have looked at the relationship of interactions with ODL instructors' attributes [12]. As researchers and ODL instructors, we feel that this needs to be looked at and understood to improve the university's fully online ODL offering. Besides, as stated by Swan [13], students who had active interaction with their instructor were found to have high levels of satisfaction with the course and higher levels of learning than students who proven to have less interaction with their instructor. Studies have shown that effective interactions have strong relation to feedback and attributes $[14,15]$. Therefore, we sought more interaction-related answers by looking at the instructor attributes and the types of feedback used in ODL courses. Cant et al. [12] have also emphasized on the fair and ethical attitude of instructors in ensuring the success of ODL. We therefore seek to validate the importance of teacher attributes as we believe that there are more attributes that should be highlighted and may even contribute to the success of online learning. This would be helpful to complement the existing findings.

\section{Research methodology}

\subsection{Design of the study}

This study used a qualitative approach. The main objective of the study was to understand the experiences of the research participants [16]. Purposive sampling was used to select participants [17]. Interviews were structured into two parts. The first part involved distribution of semi-structured interview questions through online (using google forms) to twenty postgraduate students (aged 25-50) who had enrolled in an ODL course. The second part consisted of one-on-one interviews with two instructors for data triangulation [18] and to gain a more in-depth understanding, allowing for other relevant themes to develop [19]. The confidentiality of the students and instructor was maintained by guaranteeing not to reveal their names in this study [20]. Please refer to Figure 1 for the research design. 


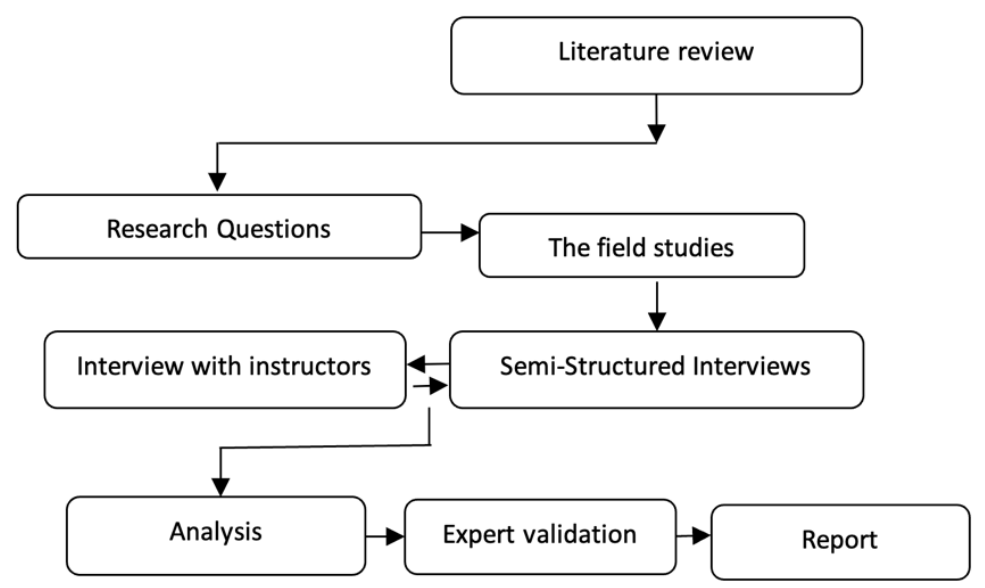

Fig. 1. Research design

\subsection{Data analysis}

Thematic analysis [21] was applied for careful analysis in finding coherent and distinctive themes by first, determining the codes and sub-themes. The entire data were coded using the NviVo software. Please refer Figure 2.

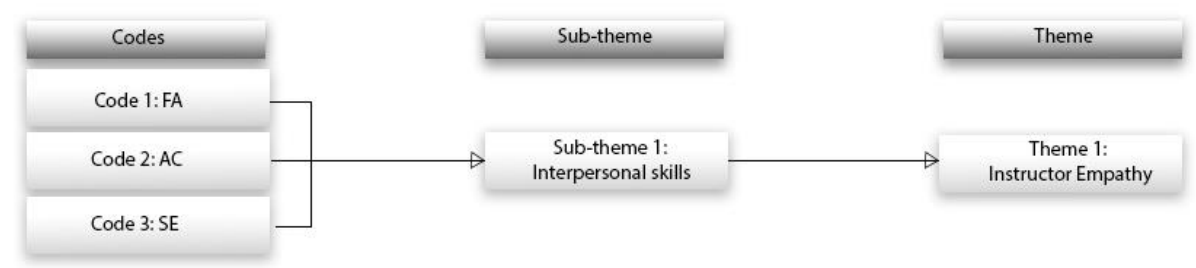

Fig. 2. Thematic analysis involves process of data familiarization, data coding, and theme development and revision

\section{$3 \quad$ Results and discussions}

Discussion is based on the two research questions to understand (1) the important attribute(s) of an ODL instructor that contribute to instructor-student interactions, and (2) the type(s) of feedback students most require from an ODL instructor. The first question is answered with the findings referring to instructor empathy and is discussed as follows: 


\subsection{Key-theme 1: Instructor empathy}

Three codes (facilitating, accommodating, and sensitive) were generated as shown in Table 1 representing the sub-theme of interpersonal interactions (Table 2) and keytheme 1 of instructor empathy. Instructor empathy or teacher empathy represents compassion and understanding shown by the teacher towards students' responses without losing the focus on the learning objectives [22]. Studies have indicated the importance of empathy through interactions to promote learning [23]. Fuller [24] suggest for faculty to promote empathy by understanding students' needs and challenges and this also has been highlighted by the students in this study. Instructor's active presence when needed have provided sense of connectedness $[25,26]$ and this has proven to be critical for ODL learning.

Table 1. Codes and indication from semi-structured interview

\begin{tabular}{|l|l|l|l|}
\hline Code & Indication & \multicolumn{1}{|c|}{ Definition } & \multicolumn{1}{c|}{ Sample of participants' quote } \\
\hline FA & Facilitating & $\begin{array}{l}\text { Facilitate activities while } \\
\text { keeping students motivated } \\
\text { and engaged. }\end{array}$ & $\begin{array}{l}\text { Student H: Sometimes it is difficult for us to } \\
\text { agree on a decision so we will refer to the instruc- } \\
\text { tor to get a more comprehensive view before con- } \\
\text { tinuing the discussion. }\end{array}$ \\
\hline AC & Accommodating & $\begin{array}{l}\text { Willing to extend help with- } \\
\text { out hesitation. }\end{array}$ & $\begin{array}{l}\text { Student G: I'm glad that I can simply message or } \\
\text { call my instructor for help at any time. There was } \\
\text { once when I message her at almost midnight, and } \\
\text { she replied! That really helps as I was under stress } \\
\text { to understand and complete the assignment given. }\end{array}$ \\
\hline SE & Sensitive & $\begin{array}{l}\text { Quick to detect or respond to } \\
\text { the surrounding, signals, or } \\
\text { feelings of others. }\end{array}$ & $\begin{array}{l}\text { Student C: It was great that we can agreed to meet } \\
\text { online at certain time, especially at night. I've to } \\
\text { rush from work after 5:00pm to get home, get my } \\
\text { kids settled...so it is a bit chaotic for me and for } \\
\text { some of my friends in the course...there was few } \\
\text { times that I can't attend the meeting but luckily } \\
\text { the instructor managed to record the meeting for } \\
\text { those who can't attend. We managed to refer back } \\
\text { to what was discussed. }\end{array}$ \\
\hline
\end{tabular}

Table 2. Categorising codes from semi-structured interviews into sub-theme

\begin{tabular}{|l|c|}
\hline Code (see Table 1) & Categorisation of codes into sub-theme \\
\hline FA, AC, SE & Interpersonal skills \\
\hline
\end{tabular}

\subsection{Sub-theme: Interpersonal skills}

The findings also indicate that instructors need to have interpersonal skills through interactions to teach effectively because interpersonal skills can influence emotions and emotions are proven to help shape student engagement and learning [27, 28]. Students in this study have stated that the facilitating, accommodating and sensitive attitude of the instructor has influenced their engagement in learning. Other studies have also reported that educators who are accommodating (supportive, kind and nurturing) has positive impact on learning $[29,30]$. The data has shown that empathize in interpersonal interactions is certainly an important skill for ODL instructors to develop and have in 
order to establish a trusting relationship [31, 32]. This also shows that empathy is the key to interpersonal skills quality [33]. Response from the instructors strongly support this finding:

- Instructor 1: We also need to understand that they are mature students with small children so we have to be tolerant and try to help them as best as we can (one-onone interview)

- Instructor 2: ...there was once, a student sends me text messages at 3:00AM! Luckily, I was still awake and able to answer her questions. I can feel that she was struggling with the assignment given (one-on-one interview)

Empathy is the ability to put yourself in other people's shoes and understand situation from their point of view. Several studies have emphasised the importance of empathy in online learning [24, 34] and this study fully supports those findings. Next, to answer the second research question, three codes (Table 3) and one sub-theme (Table 4) were generated with the formulation of key-theme 2 (feedback to empower learners).

\subsection{Key-Theme 2: Feedback to empower learners}

All four codes (Table 3) and one sub-theme (Table 4) identified in the study lead to characteristics of feedback to empower learners. Studies have indicated that constructive feedback (debate, reflection, and explanatory) able to encourage empowerment by improving self-confidence and problem-solving skills among students [35-37]. Therefore, this study suggests the feedback to be applied in other ODL courses and analysed for future studies.

Table 3. Codes and indication from semi-structured interview

\begin{tabular}{|l|l|l|l|}
\hline Code & Indication & \multicolumn{1}{|c|}{ Definition } & \multicolumn{1}{|c|}{ Sample of participants' quote } \\
\hline DB & Debates & $\begin{array}{l}\text { Discussion involves op- } \\
\text { posing arguments. }\end{array}$ & $\begin{array}{l}\text { Student H:...the instructor sometimes disagrees with our } \\
\text { choice of design, but we can argue and state our reasons } \\
\text { of choice...it's good to argue. }\end{array}$ \\
\hline RF & Reflection & $\begin{array}{l}\text { Serious thought in making } \\
\text { decision. }\end{array}$ & $\begin{array}{l}\text { Student G: We need to do three levels of reflection on } \\
\text { our own design for assignment 3 and this has allowed us } \\
\text { to think critically and made us feel more confident with } \\
\text { the final outcome. }\end{array}$ \\
\hline EX & Explanatory & $\begin{array}{l}\text { Offering hint or tips for } \\
\text { further exploration. }\end{array}$ & $\begin{array}{l}\text { Student C: She normally doesn't give direct answers in- } \\
\text { stead, she gave us for example, links to related resources } \\
\text { and asked us to explore further before continuing to dis- } \\
\text { cuss. }\end{array}$ \\
\hline
\end{tabular}

Table 4. Categorising codes from semi-structured interviews into sub-theme

\begin{tabular}{|l|c|}
\hline \multicolumn{1}{|c|}{ Code (see Table 3) } & Categorisation of codes into sub-theme \\
\hline DB, RF, EX & Constructive feedback \\
\hline
\end{tabular}




\subsection{Sub-theme: Constructive feedback}

We tried to understand the type of feedback that can aid learning especially among mature learners in ODL. The emerging codes (debates, reflection, and explanatory) represent the characteristics of constructive feedback as they were found helpful, encouraging, and able to reinforce learning [38-40]. Giving constructive feedback is a skill that require practice $[39,41]$ and relates closely to empowerment $[42,43]$. The ODL instructor (Instructor 2) verified this by stating that trainings should be given to all ODL instructors in giving constructive feedback as it can affect students' motivation and retention to learn.

- Instructor 2: We need to be skilful in giving constructive feedback to mature students, they can just withdraw from our ODL courses if we are not careful. They are not undergraduate students; they have different expectations (one-on-one interview).

- Instructor 2: ... you can identify a few students who require constant motivation. Instructors need to show care and give lots of encouragement to the students... but there are also those who like challenges! [Laugh] but the challenge must be given with proper support (one-on-one interview).

Instructors were found to provide various styles of feedback to students e.g., challenge and support were given concurrently and this illustrates constructive feedback [44] which has an impact on students' empowerment $[45,46]$.

\section{Conclusion}

This study has obtained two important factors that need to be considered to ensure successful learning in fully online ODL among mature students namely (1) instructor empathy (2) feedback to empower learners. Instructors must first and foremost, develop interpersonal skills and learn to provide constructive feedback. This study therefore recommends for faculty to provide adequate trainings to instructors and only assign qualified academic staff to teach in ODL if wish to sustain the ODL offering. With the recommendations, it is hoped that this article will spark helpful conversation for continued investigation of instructor attribute and feedback in fully online ODL environment.

\section{$5 \quad$ Limitations and future studies}

This study involved a small sample of university postgraduate students and academics in one of Malaysia public universities therefore the findings cannot be generalized. However, the findings can provide important information for future research. 


\section{Acknowledgement}

Malaysia Ministry of Education (MOE), Fundamental Research Grant Scheme (FRGS) - R.J130000.7816.4F937.

\section{$7 \quad$ References}

[1] Mahlangu, V.P., The good, the bad, and the ugly of distance learning in higher education. Trends in E-learning, 2018: p. 17-29. https://doi.org/10.5772/intechopen.75702

[2] Welch, A. and L. Napoleon, Professional teaching dispositions of online instructors: Why they matter. Procedia-Social and Behavioral Sciences, 2015. 171: p. 584-589. https://doi.org/10.1016/j.sbspro.2015.01.164

[3] Edwards, M., B. Perry, and K. Janzen, The making of an exemplary online educator. Distance Education, 2011. 32(1): p. 101-118. https://doi.org/10.1080/01587919.2011.565499

[4] Kiriakidis, P. Three Important Teaching Qualities of Online Instructors Facilitating Instructor and Learner Discourse (ILD). in E-Learn: World Conference on E-Learning in Corporate, Government, Healthcare, and Higher Education. 2008. Association for the Advancement of Computing in Education (AACE).

[5] Patrick, P.K. and A.G. Yick, Standardizing the interview process and developing a faculty interview rubric: An effective method to recruit and retain online instructors. The Internet and higher education, 2005. 8(3): p. 199-212. https://doi.org/10.1016/j.iheduc.2005.06.002

[6] Dzakiria, H., R.M. Idrus, and H. Atan, Interaction in Open Distance Learning: Research Issues in Malaysia. Malaysian Journal of Distance Education 2005. 7(2): p. 63-77.

[7] Dzakiria, H., et al., Effective learning interaction as a prerequisite to successful open distance learning (ODL): A case study of learners in the northern state of Kedah and Perlis, Malaysia. Turkish Online Journal of Distance Education, 2013. 14(1): p. 111-125.

[8] Adelakun, L.A., Trends in Using Social Media as Substitute for Class Interaction in Open \& Distance Learning (Odl) Education in Nigeria. International Journal of Pedagogy, Policy and ICT in Education, 2018. 6(1): p. 33-42.

[9] Courville, K., Technology and Its Use in Education: Present Roles and Future Prospects. Online Submission, 2011.

[10] Guri-Rosenblit, S., Distance education teachers in the digital age: New roles and contradictory demands. Learner support in open, distance and online learning environments, 2004. 9: p. 63-70.

[11] Parker, A., Interaction in distance education: The critical conversation. AACE Review (formerly AACE Journal), 2020: p. 13-17.

[12] Cant, M.C., J.A. Wiid, and R. Machado, The characteristics of a good ODL practitioner. Gender and Behaviour, 2013. 11(2): p. 5673-5687. https://doi.org/10.19030/iber.v12i11. $\underline{8170}$

[13] Swan, K., Virtual interaction: Design factors affecting student satisfaction and perceived learning in asynchronous online courses. Distance education, 2001. 22(2): p. 306-331. https://doi.org/10.1080/0158791010220208

[14] Ossenberg, C., A. Henderson, and M. Mitchell, What attributes guide best practice for effective feedback? A scoping review. Advances in Health Sciences Education, 2019. 24(2): p. 383-401. https://doi.org/10.1007/s10459-018-9854-x

[15] Wanner, T. and E. Palmer, Formative self-and peer assessment for improved student learning: the crucial factors of design, teacher participation and feedback. Assessment \& Evaluation in Higher Education, 2018. 43(7): p. 1032-1047. https://doi.org/10.1080/02602938 .2018 .1427698 
[16] Denscombe, M., The Good Research Guide: for small-scale social research projects. 2010: McGraw-Hill Education.

[17] Punch, K.F., Introduction to Social Research: Quantitative and Qualitative Approaches. 2013: SAGE Publications.

[18] Flick, U., Concepts of triangulation, in Managing Quality in Qualitative Research (2nd edition). 2018, SAGE Publications Ltd. p. 38-54.

[19] Choak, C., Asking questions: interviews and evaluations, in Research and Research Methods for Youth Practitioners 1st Edition, S. Bradford and F. Cullen, Editors. 2011, Routledge: London. p. 240.

[20] Allen, M., The SAGE Encyclopedia of Communication Research Methods. 2017: SAGE Publications. https://doi.org/10.4135/9781483381411

[21] Braun, V. and V. Clarke, Using thematic analysis in psychology. Qualitative Research in Psychology, 2006. 3: p. 77-101. https://doi.org/10.1191/1478088706qp063oa

[22] Meyers, S., et al., Teacher empathy: A model of empathy for teaching for student success. College Teaching, 2019. 67(3): p. 160-168. https://doi.org/10.1080/87567555.2019. 1579699

[23] Feng, J., J. Lazar, and J. Preece, Empathy and online interpersonal trust: A fragile relationship. Behaviour \& Information Technology, 2004. 23(2): p. 97-106. https://doi.org/ $\underline{10.1080 / 01449290310001659240}$

[24] Fuller, R.G., Building empathy in online courses: Effective practical approaches. International Journal of Information and Communication Technology Education (IJICTE), 2012. 8(4): p. 38-48. https://doi.org/10.4018/jicte.2012100104

[25] Shea, P., C.S. Li, and A. Pickett, A study of teaching presence and student sense of learning community in fully online and web-enhanced college courses. The Internet and higher education, 2006. 9(3): p. 175-190. https://doi.org/10.1016/j.iheduc.2006.06.005

[26] Almusharraf, N. and S. Khahro, Students satisfaction with online learning experiences during the COVID-19 pandemic. International Journal of Emerging Technologies in Learning (iJET), 2020. 15(21): p. 246-267. https://doi.org/10.3991/ijet.v15i21.15647

[27] Linnenbrink-Garcia, L. and R. Pekrun, Students' emotions and academic engagement: Introduction to the special issue. Contemporary Educational Psychology, 2011. 36(1): p. 1-3. https://doi.org/10.1016/j.cedpsych.2010.11.004

[28] Vlachopoulos, D. and A. Makri, Quality Teaching in Online Higher Education: The Perspectives of 250 Online Tutors on Technology and Pedagogy. International Journal of Emerging Technologies in Learning (iJET), 2021. 16(6): p. 40-56. https://doi.org/10. 3991/ijet.v16i06.20173

[29] Pit-ten Cate, I.M., et al., Promoting Inclusive Education: The Role of Teachers' Competence and Attitudes. Insights into Learning Disabilities, 2018. 15(1): p. 49-63.

[30] Feshbach, N.D. and S. Feshbach, Empathy and education. The social neuroscience of empathy, 2009. 85: p. 98. https://doi.org/10.7551/mitpress/9780262012973.003.0008

[31] Duffy, F.D., et al., Assessing competence in communication and interpersonal skills: the Kalamazoo II report. Academic Medicine, 2004. 79(6): p. 495-507. https://doi.org/10.1097/ 00001888-200406000-00002

[32] Ag-Ahmad, N., Open and Distance Learning (ODL): Preferences, Issues and Challenges amidst Covid-19 Pandemic. Journal of Creative Practices in Language Learning and Teaching (CPLT), 2020. 8(2).

[33] Lloyd, C. and F. Maas, Interpersonal skills and occupational therapy. British Journal of Occupational Therapy, 1992. 55(10): p. 379-382. https://doi.org/10.1177/03080226920 5501005

[34] Osler, L., Taking empathy online. Inquiry, 2021: p. 1-28. https://doi.org/10.1080/ 0020174X.2021.1899045 
[35] Louden, A.D. and I.D.E. Association, Navigating Opportunity: Policy Debate in the 21st Century: Wake Forest National Debate Conference. 2010: International Debate Education Association.

[36] Ghaye, T. and S. Lillyman, Empowerment Through Reflection: A Guide for Practitioners and Healthcare Teams. 2011: Quay Books.

[37] Killingsworth, S.S., D.B. Clark, and D.M. Adams, Self-explanation and explanatory feedback in games: Individual differences, gameplay, and learning. International Journal of Education in Mathematics, Science and Technology, 2015. 3(3): p. 162-186.

[38] Ovando, M.N., Constructive feedback. International Journal of Educational Management, 1994. https://doi.org/10.1108/09513549410069185

[39] Duffy, K., Providing constructive feedback to students during mentoring. Nursing Standard (through 2013), 2013. 27(31): p. 50.

[40] Al-Hattami, A.A., The Perception of Students and Faculty Staff on the Role of Constructive Feedback. International Journal of Instruction, 2019. 12(1): p. 885-894. https://doi.org/10. 29333/iji.2019.12157a

[41] Mahlangu, V.P., Exploring Challenges of Supervising Postgraduate Students in Open Distance Learning in Higher Education Settings. 2021.

[42] Broom, C., Empowering students: Pedagogy that benefits educators and learners. Citizenship, Social and Economics Education, 2015. 14(2): p. 79-86. https://doi.org/10.1177 /2047173415597142

[43] Feidakis, M., et al., Embedding emotion awareness into e-learning environments. International Journal of Emerging Technologies in Learning (iJET), 2014. 9(7): p. 39-46. https://doi.org/10.3991/ijet.v9i7.3727

[44] Bee, R. and F. Bee, Constructive Feedback. 1998: Institute of Personnel and Development.

[45] Evans, C. and M. Kozhevnikov, Styles of Practice in Higher Education: Exploring approaches to teaching and learning. 2016: Taylor \& Francis. https://doi.org/10.4324/ 9781315540382

[46] Aslam, R. and N. Khan, Constructive feedback and Students' academic achievement: a theoretical framework. New Horizons, 2020. 14(2): p. 175.

\section{Authors}

Zaleha Abdullah is a creative content expert and has held several positions e.g., UTM Director of Corporate Affairs and Manager for a collaborative project with the Massachusetts Institute of Technology (MIT). Her research interest includes online and distance learning, creativity, visual communication, and leadership (Email: zac@ utm.my).

Mohd Nihra Haruzuan Mohamad Said is a senior lecturer at Universiti Teknologi Malaysia. His interests lie at the intersection of Educational Technology, Virtual Learning management system, Online learning, Multimedia-based learning and New Media in Education (Email: nihra@utm.my).

Article submitted 2021-10-04. Resubmitted 2021-10-22. Final acceptance 2021-11-14. Final version published as submitted by the authors. 